\title{
QUATERNARY DEVELOPMENT OF RESILIENT REEFS ON THE SUBSIDING KIMBERLEY CONTINENTAL MARGIN, NORTHWEST AUSTRALIA*
}

\author{
Lindsay B. Collins ${ }^{1 * *}$ and Viviane Testa ${ }^{1,2}$ \\ ${ }^{1}$ Department of Applied Geology, Curtin University of Technology \\ (Bentley, 6102, Western Australia)
}

${ }^{2}$ Universidade Federal do Espírito Santo - Departamento de Ecologia e Recursos Naturais

(Av. Fernando Ferrari, s/n, Goiabeiras, 29070-900 Vitória, ES, Brasil)

**1.collins@ @urtin.edu.au

\begin{abstract}
A B S TR ACT
The Kimberley region in remote northwest Australia has poorly known reef systems of two types; coastal fringing reefs and atoll-like shelf-edge reefs. As a major geomorphic feature (from $12^{\circ} \mathrm{S}$ to $18^{\circ} \mathrm{S}$ ) situated along a subsiding continental margin, the shelf edge reefs are in a tropical realm with warm temperatures, relatively low salinity, clear low nutrient waters lacking sediment input, and Indo-West Pacific corals of moderate diversity. Seismic architecture of the Rowley Shoals reveals that differential pre-Holocene subsidence and relative elevation of the pre-Holocene substrate have controlled lagoon sediment infill and reef morphology, forming an evolutionary series reflecting differential accommodation in three otherwise similar reef systems. The Holocene core described for North Scott Reef confirms previous seismic interpretations, and provides a rare ocean-facing reef record. It demonstrates that the Indo-Pacific reef growth phase (RG111) developed during moderate rates of sea level rise of $10 \mathrm{~mm} /$ year from 11 to about 7-6.5 ka BP until sea level stabilization, filling the available $27 \mathrm{~m}$ of pre-Holocene accommodation. Despite the medium to high hydrodynamic energy imposed by the $4 \mathrm{~m}$ tides, swell waves and cyclones the reef-building communities represent relatively low-wave energy settings due to their southeast facing and protection afforded by the proximity of the South Reef platform. This study demonstrates the resilience of reefs on the subsiding margin whilst linking Holocene reef morphology to the relative amount of pre-Holocene subsidence.
\end{abstract}

\section{RESUMO}

Kimberly é uma região remota e pouco conhecida, localizada no noroeste da Austrália, ali são encontrados dois sistemas recifais: recifes costeiros de franja e os tipo-atois localizados na margem da plataforma continental. Esses recifes formam a feição geomórfica mais importante entre $12^{\circ} \mathrm{S}$ a $18^{\circ} \mathrm{S}$ estando localizados ao longo de uma margem continental em subsidência. Esses recifes encontram-se em um ambiente tropical com temperaturas altas, salinidade relativamente baixa, águas claras com baixa concentração de nutrientes, sem aporte de sedimentos continentais e contendo uma fauna indo-pacífica de diversidade moderada. A arquitetura sísmica do Roley Shoals revela que a subsidência diferencial pré-holocênica e elevações relativas do substrato pré-holocênico controlaram a morfologia e o preenchimento de sedimentos na lagoa. Esta formou uma evolução em série que reflete o espaço de acomodação diferente em sistemas recifais que, de outra forma, seriam considerados semelhantes. O testemunho holocênico descrito para North Reef confirma a interpretação sísmica anterior, e contribui com um raro registro de uma frente recifal em ambiente de mar aberto. Os dados mostram que a fase de crescimento do recife indo-pacífico (RG111) apresentou razões moderadas de elevação do nível do mar de $10 \mathrm{~mm} /$ ano entre 11 e aproximadamente 7-6,5 anos BP, até a estabilização do nível do mar, preenchendo assim 27 metros de espaço de acomodação préholocênica. Apesar da média a alta energia hidrodinâmica imposta pelos $4 \mathrm{~m}$ de amplitude de maré, ondas de alto-mar e furacões, as comunidades construtoras dos recifes representam ambientes relativamente de baixa energia. O presente estudo demonstra a resiliência de recifes de margem de subsidência e relaciona também a morfologia recifal do holoceno à quantidade relativa de subsidência pré-holoceno.

Descriptors: Coral reefs, Carbonate platform, Seismic architecture, Quaternary, Holocene, Sea-level, Geochronology, Geomorphology, Australia.

Descritores: Recifes de corais, Plataforma carbonática, Arquitetura sísmica, Quaternário, Holoceno, Nível do mar, Geocronologia, Geomorfologia, Australia.

(*) Paper presented at the INTERNATIONAL GEOLOGICAL CORRELATION PROGRAM PROJECT NO. 526 - RISKS, RESOURCES, AND RECORD OF THE PAST ON THE CONTINENTAL SHELF: MINING LATE QUATERNARY GEOLOGICAL EVIDENCE, 2., 2008, Natal, UFRN. 


\section{INTRODUCTION}

The remote northwest region of Australia is a deeply embayed tropical macrotidal coast, fringed by an onshore complex of Proterozoic rocks known as the Kimberley Block, which is bordered by Cenozoic carbonate ramps (Fig. 1). Although this area is sparsely populated and poorly known, the recognition of a major hydrocarbon province in the offshore has led to increased surveys and awareness of a rich biodiversity (COLLINS, 2002; CHIN et al., 2008). Coral reefs are widespread along the Kimberley coast and comprise a major geomorphic feature along the continental shelf edge from $12^{\circ} \mathrm{S}$ to $18^{\circ} \mathrm{S}$.

Marginal to the Sahul Shelf (north Kimberley) and close to Timor are a series of isolated submerged shoals (Echo Shoals, Big Bank and Karmt) and reefs (Ashmore Reef; Cartier Island, Seringapatam, Scott Reef and the Rowley Shoals) (HEYWARD et al., 1997). The shoals formed a string of banks seaward of the palaeo-coastline and were drowned in the last 20000 years (LAVERING, 1993), terminating the major carbonate production derived from corals. Thereafter, the carbonate accumulation that maintains many of the banks derives from the in situ growth of Halimeda and accumulation of its fragments with contribution from a diverse reef biota of lesser abundance (HEYWARD et al., 1997). In contrast, the reefs along the west Kimberley coast are essentially of two types: coastal fringing reefs and isolated offshore reefs bordering the shelf edge.

Fringing reefs intermittently occur along an extensive portion of the coastal region. These reefs are very poorly known and endure in a remarkably inhospitable environment with high sediment input and high hydrodynamic energy, but they have been suggested to be of international significance and are in need of intensive study (CHIN et al., 2008).

The most significant offshore reefs are the Rowley Shoals around $17^{\circ} \mathrm{S}$ and Scott Reef at $14^{\circ} \mathrm{S}$ (Fig. 1). These reefs and associated small carbonate platforms were formed along a Miocene continental margin, and the reefs have maintained their development despite rapid subsidence of the shelf edge since the mid-Miocene. The modern reefs are subject to cyclones and bleaching (SMITH et al., 2008; HEYWARD et al., 1997) and their remote location and distance from the coast (up to $400 \mathrm{~km}$ ) positions these reefs amongst the most pristine environments remaining in the world (CHIN et al., 2008). These reefs remain poorly known geologically since the pioneering studies of Fairbridge (1950), unlike the relatively well studied Great Barrier Reef, on Australia's northeast coast (HOPLEY et al., 2007).

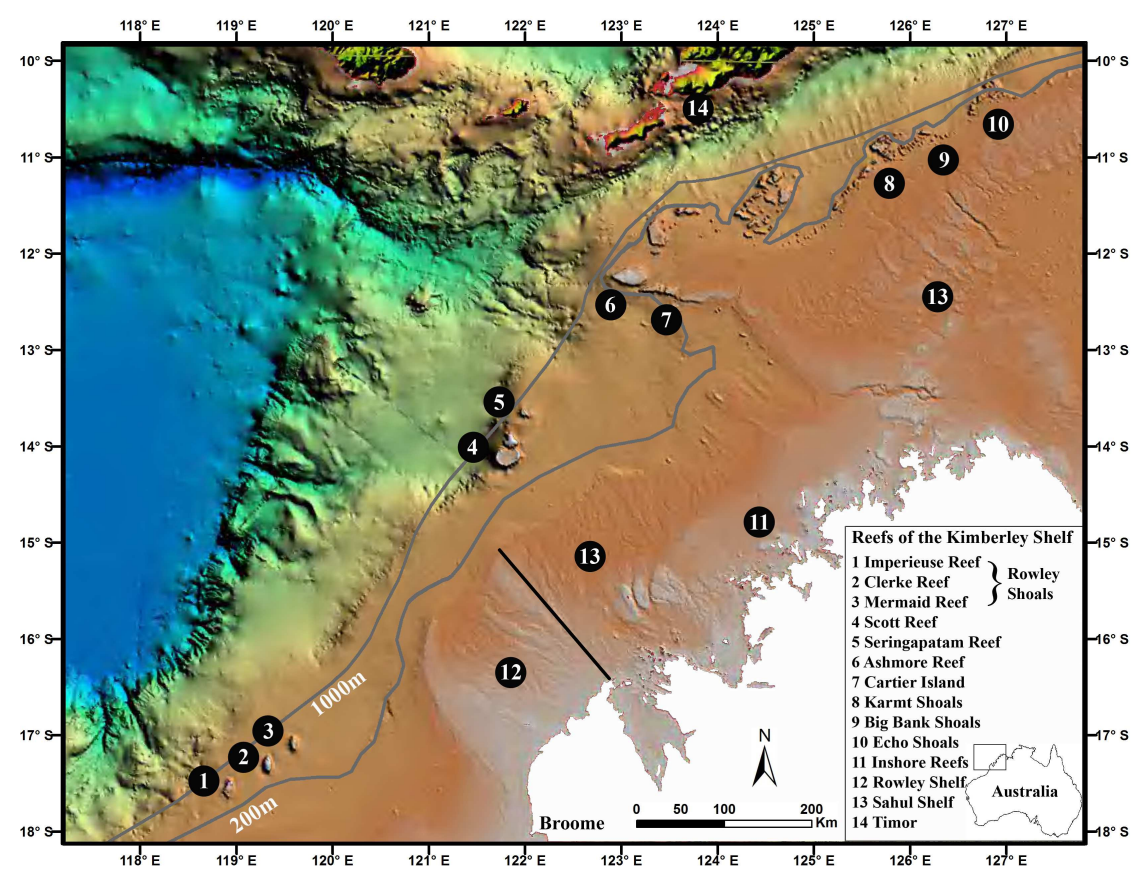

Fig. 1. Location map of the Kimberley region, northwest Australia, showing shelf edge reefs, particularly Scott Reef and the Rowley Shoals. Black line marks the boundary between Rowley Shelf (12) and Sahul Shelf (13). 
Whilst the understanding of the fringing reefs of the Kimberley still remains a gap in our knowledge, here we describe aspects of the morphology, internal architecture and Quaternary growth history of some of the offshore reefs which border the continental shelf of the Kimberley region, particularly the Rowley Shoals and Scott Reef, based on seismic and limited core data, providing the first account of Quaternary reef architecture for two of the northern-most coral reef systems of Western Australia. This study demonstrates the resilience of reefs on the subsiding margin whilst linking Holocene reef morphology to the relative amount of pre-Holocene subsidence.

Characteristics of the Study Area

The Kimberley region extends approximately between $12^{\circ}$ to $18^{\circ} \mathrm{S}$ and from $118^{\circ}$ to $122^{\circ} \mathrm{E}$. Its continental shelf and margin are in the domain of the Indian South Equatorial Current. It is situated in a tropical marine realm, with warm temperatures between $26-28^{\circ} \mathrm{C}$, and slightly lowered salinity $(34.5$ to 35.7$)$ that characterizes the waters in the proximity of the Indonesian Throughflow. Offshore areas have clear waters due to low nutrient levels and no continental sediment input, due to distance from the coast, providing an ideal environment for the development of coral reef communities. The waters from the Eastern Indian Ocean combined with the input of waters derived from the Indonesian Throughflow in the North West Shelf results in sea levels in the tropics being $0.5 \mathrm{~m}$ higher than along the southern coast of Australia (PEARCE; GRIFFITHS, 1991). With higher tropical sea levels, the formation of a north-south pressure gradient induces a weak easterly flow of central Indian Ocean subtropical water towards the Australian coast between $15-35^{\circ} \mathrm{S}$ (PEARCE; GRIFFITHS, 1991). This easterly flow is deflected south by the coastline, eventually contributing to the Leeuwin Current (Fig. 1). The proximity to the Indonesian Throughflow has been shown to increase the importance of both Pacific and Asian reef species southward, and the Leeuwin Current, which flows southwards against the prevailing equatorward winds, is an important control on southward larval delivery, whilst suppressing upwelling along its path (FANG ;MORROW, 2003).

The North West Shelf is tidally dominated, with coastal mean spring range increasing from $1.7 \mathrm{~m}$ at Exmouth to $9.2 \mathrm{~m}$ in King Sound (HARRIS et al., 1991). Both Scott Reef and Rowley Shoals have semidiurnal tides with a tidal range of 4.1 and 4.5 respectively (NATIONAL TIDAL CENTER, 2009a, b; meso-high tidal range, sensu Hayes 1975). The region lies in the monsoonal belt with prevailing westerly or northwesterly rain- bearing winds from
November-March, and dry southeasterly or easterly trade winds from May to September. The region is cyclone-influenced (average 3 per year from equatorial latitudes, Lough, 1998) and has southwest prevailing swell.

Coral assemblages at Scott Reef and Rowley Shoals are tropical Indo-Pacific and diverse, with 56 genera and 233 species recorded for Scott Reef, and 52 genera and 184 species recorded for Rowley Shoals (BERRY ; MARSH, 1986), whilst the reefs of the Kimberley coast have only about 106 species (VERON, 1993) . Hard coralline red algal pavements and stunted corals characterize high energy areas, with high coral cover and diverse growth forms in sheltered habitats. Average coral cover in monitored reef slopes reduced from $47 \%$ to $1 \%$ after a cyclone in 1995 , and extensive bleaching was recorded at Scott Reef in 1998 following a period of warm water temperatures for several weeks; sites with $54 \%$ coral cover were reduced to $10 \%$ live cover by this event. Reef monitoring showed that after six years, approximately $40 \%$ of the hard corals recovered, accompanied by a clear change in the community structure which had been observed pre-bleaching (SMITH et al., 2006; 2008).

\section{Materials And Methods}

Offshore field surveys were carried out using the CSIRO research vessel RV Franklin during Voyage FRO5/00. Both shipboard and small vessel seismic surveys were conducted using an ORE Model 581 3A Acoustic Source (Boomer), driven by a Geopulse 5420A power supply. A Benthos multielement streamer was used for small vessel work and a Teledyne 4 channel streamer was used for Franklin work. The seismic acquisition system used was a Geoacoustics SE88 1 Sonar Enhancement System, and a Garmin GPS unit supplied GPS data to the acquisition system on the small vessel. Franklin DGPS data were supplied and processed by Navipac software for onboard seismic acquisition.

Oceanographic data was acquired using CTD, and bathymetric data by PDR. Geological sampling was by Epibenthic Sled and Gravity Corer. No core data was obtained for the Rowley Shoals, and limited core was available for Scott Reef. Cores were logged and dated using U series TIMS methods (University of Queensland, Centre for Microscopy and Microanalysis) by the dating techniques of Zhao et al. (2001) and Yu et al. (2006). Borehole NR1 was acquired in 11 meters water depth in the fore-reef zone of North Reef. Lithologies were characterized using the Extended Dunham Classification (EMBRY; KLOVAN 1971) for depositional textures, and the characterization of main biological facies followed the scheme of Montaggioni (2005). 


\section{RESULTS}

Reef Morphology

The Rowley Shoals comprise a group of three offshore isolated reefs, the Mermaid $\left(17^{\circ} 06^{\prime} \mathrm{S}\right.$ $\left.119^{\circ} 37^{\prime} \mathrm{E}\right)$, Clerke $\left(17^{\circ} 19^{\prime} \mathrm{S}-119^{\circ} 21^{\prime} \mathrm{E}\right)$ and Imperieuse $\left(17^{\circ} 35^{\prime} \mathrm{S} 118^{\circ} 55^{\prime} \mathrm{E}-17.583^{\circ} \mathrm{S}\right)$ reefs. Scott Reef lies on the Scott Plateau and comprises two reefs, North Reef and South Reef $\left(14^{\circ} 03^{\prime} \mathrm{S}-121^{\circ} 46^{\prime} \mathrm{E}\right)$, separated by a narrow and deep channel. The reefs rise from 200-800 m water depths as isolated ramp margin features that have survived through sea level oscillations and subsidence since the Miocene. Whilst little is known of the foundations of the Rowley Shoals some similarities are expected with the Scott Plateau whose stratigraphy is reasonably well understood from exploration activities.

The Scott Plateau and its northeastern extension delineate the western limit of the Browse Basin. Seismic data suggest that the plateau consists of uplifted, relatively shallow Palaeozoic and Precambrian rocks overlain by thin $(<1000 \mathrm{~m})$ Cretaceous and younger sediments (STEPHENSON; CADMAN, 1994; SYMONDS et al., 1994). Near the end of the Triassic a major compressional event resulted in the generation of a series of large anticlines and synclines, including the Scott Reef and Brecknock trends (STRUCKMEYER et al., 1998). Post-breakup transgressive marine shales and claystones covered the Scott Reef trend by the Late Tithonian, and claystones, siltstones and marls dominate the Cretaceous section. A $3515 \mathrm{~m}$ section of Paleocene-Quaternary carbonates (mainly calcarenite, calcilutite and marl, with minor chert) underlies the Scott Reef platform (BOC OF AUSTRALIA, 1971a, b). The top 1,700 m consists of an undated reef complex which is partially dolomitised.

The Rowley Shoals (Mermaid, Clerke and Imperieuse Reefs, Fig.2a) were described as the most perfect morphological examples of shelf atolls in Australian waters (FAIRBRIDGE, 1950). The three shoals have similar dimensions, shape, orientation and distance apart, and all rise from the distal ramp of the North West Shelf. From northeast to southwest the reefs rise from progressively shallower depths on their landward sides; Mermaid Reef from $440 \mathrm{~m}$, Clerke Reef from 390 m, and Imperieuse Reef from $230 \mathrm{~m}$. Each atoll (length range 15-17 km, width range 7-9 $\mathrm{km}$ ) has north-south orientation, is pear-shaped with the narrower end to the north, and has a reef which encloses a single central lagoon which is ovoid and relatively deep in Mermaid Reef, but becomes increasingly shallow and segmented in Clerke and lmperieuse reefs. About two thirds of the way up its eastern side, each system has a narrow passage (or passages), through which tidal flushing and sediment exchange occur (BERRY; MARSH, 1986).

Mermaid Reef (Fig. 2a) has, on its western side, an outer reef flat ( $0.5 \mathrm{~km}$ wide) which is exposed at low tide, and a back reef of similar width, backed by a $1 \mathrm{~km}$ wide sand flat. The eastern margin is only 0.6 $\mathrm{km}$ wide and the sand flat is absent. The western outer reef slope has well-developed spur and groove, the outer reef has slow-growing coralline red algae and corals, while the back reef flat has a cover of living and dead coral and algal turf (BERRY; MARSH, 1986). At Clerke Reef the shallow ( $<10 \mathrm{~m})$ lagoon is segmented into three parts by sand sheet development (COLLINS, 2002). Imperieuse Reef has a lagoon partitioned into three basins by sand sheet development but the two along the eastern edge are deeper than the larger, central basin which is extensively infilled by a meshwork of coral growth, composed of flat-topped coalescent reef with intervening sand-floored depressions. The coral assemblages described for Scott Reef by Done et al. (1994) are also recorded at Rowley Shoals. Differences in reef morphology, hydrodynamic exposure and ponding are reflected in the assemblages.

Scott Reef (Fig. 2b) rises from depths of 400$800 \mathrm{~m}$ on the distal portion of a carbonate ramp, and is similar in setting to 'downslope buildups' (sensu READ, 1985). It is a complex of two large isolated coral reefs separated by a deep channel; the pearshaped North Reef and the crescent-shaped South Reef (BERRY; MARSH, 1986; see Fig. 2b). North Scott Reef is continuous except for two narrow passages, one in the southwest, and one in the northeast, with similar reef flat dimensions throughout. The outer reef flat is a mixture of scattered large boulders and occasional living corals. The outer reef gives way on its seaward margin to a gentle slope followed by an irregular outer slope with surge channels extending to $30 \mathrm{~m}$ and steep gradient to seaward. The inner reef has low coral cover, some algal turf, and lacks a distinct boulder zone. The back reef is deeper, with a more diverse coral fauna, and the lagoon is sandy with scattered corals (DONE et al., 1994).

South Reef is open to the north, and is $27 \mathrm{~km}$ wide (east - west) and $20 \mathrm{~km}$ from north to south. The distance between the reefs is $5 \mathrm{~km}$ and the intervening channel is $400-700 \mathrm{~m}$ deep. The reef flat of the western part of South Scott Reef is over $2 \mathrm{~km}$ wide, and $600 \mathrm{~m}$ of reef flat is emergent at low water. Sandy Islet (Fig. 2b) is a small, unvegetated sand cay situated atop a detached northwesterly portion of the reef. The eastern part of the reef is similar in morphology to the west reef, also with a detached sand cay, which is the only portion emergent at low water. The outer reef generally has encrusting coralline red algae and minor corals, and the reef flat includes boulder rubble, sand flats, algal turf and minor amounts of coral. The back 
reef is sandy with scattered large Porites colonies, other corals and sparse seagrass. Lagoon depths inside South Scott Reef are 35- 55 m (ca.30 m in North Reef) and there are isolated coral knolls, sandy areas, and hard substrates with sponges and stunted coral communities (DONE et al., 1994).

Only very limited portions of the reef crest of both reefs is exposed during low tide, leaving the majority of the reef structure submerged and prone to colonization by reef- related communities. Both reef crests and lagoons have prolific development of coral patch reefs and other reef communities in association with large amounts of reworked boulders to gravel size reef fragments, reworked by episodic cyclonic storms (GILMOUR; SMITH 2006) and the general high hydrodynamic energy of 4 metre tides and swells.

Coral assemblages identified by Done et al. (1994) were: Staghorn Acropora thickets, with moderate diversity of massive and branching corals (deep inner reef flats), Goniastrea retiformis/Porites massive community (sheltered reef flats and lagoon slopes), Acropora brueggemanni thickets (areas with moderate water motion), faviid, pocilloporid and Acropora palifera assemblage (areas with moderatestrong water motion), and the 'Staghorn plus' assemblage (lagoon floors).

\section{Platform/Reef Architecture}

Little is known of the Quaternary geology and reef growth history, and there is a lack of surface outcrop, so seismic profiles of the Mermaid and Imperieuse Reefs, particularly their lagoons and reef crests, were conducted to assess the Quaternary reef growth pattern and the style of platform sedimentation (see discussion in Collins, 2002). At least two stages of reef growth (last interglacial and Holocene) were identified, separated by a prominent seismic discontinuity (mapped as R1). The nature of the last interglacial reef platform, its substrate and topography, particularly the geometry and elevation of its palaeotopography (eg. lagoon and reefs), exert antecedent controls on Holocene reef growth. The type and pattern of Holocene reef growth, and the amounts and location of Holocene reef building and sand sheet development in the lagoon and at the marginal reef crests reflect Holocene reef growth on a saucershaped, last interglacial platform surface.

The Rowley Shoals are characterised both by striking similarities and by significant differences. They are similar in gross morphology (ovoid shape, with annular reef and central lagoon; similar length and width) and similar in their down- ramp setting, except that they rise from increasing depths to the northeast, from $230 \mathrm{~m}$ at Imperieuse Reef to $440 \mathrm{~m}$ at Mermaid Reef. Their oceanographic and physical process setting is similar, in terms of wind, wave and tidal regimes. The difference between the reefs lies in the morphological series manifested by an increasing degree of lagoon infill from northeast to the southwest, from the open, ovoid and $20 \mathrm{~m}$ deep Mermaid lagoon, through the partially infilled and partitioned Clerke lagoon, to the shallow, more fully infilled Imperieuse lagoon (Fig. 2).

The concept of the coral reef as a "leaky bucket", in terms of the amount of lagoon sediment retained or alternatively, permanently lost to the system by sediment transport, has had a long history (ZHU et al., 1993). This principle could be invoked to explain the series of differential lagoon infills referred to, and indeed Mermaid Reef (with the deepest and most open lagoon) has a $60 \mathrm{~m}$ wide leeward channel through which active sediment transport is occurring, and a plume of expelled lagoon sediment was detected in nearby seafloor samples collected at $400 \mathrm{~m}$ depth. Similar northeasterly leeward channels at Clerke and Imperieuse Reefs are poorly developed, only a few metres wide, and transport much smaller sediment loads. These lagoons apparently retain far more sediment than Mermaid Reef.
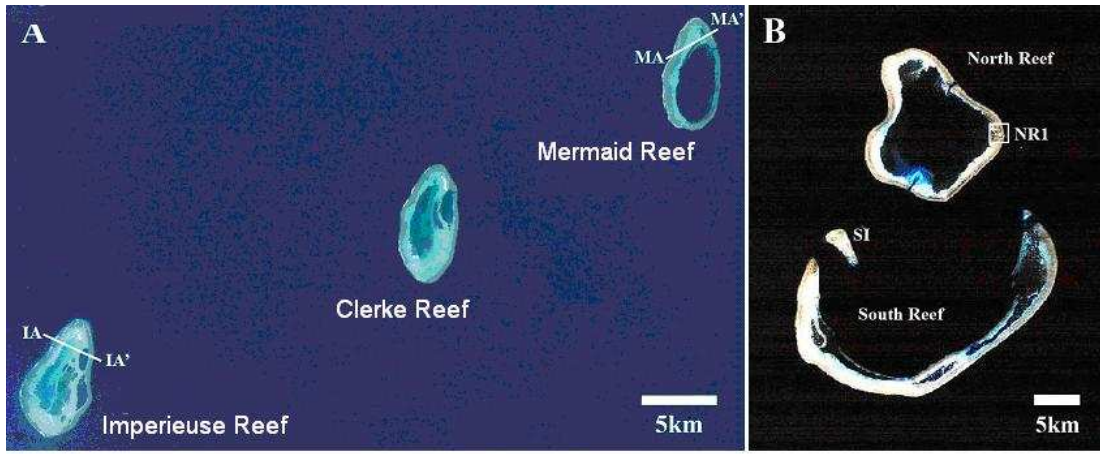

Fig. 2. Landsat images of a) Rowley Shoals and b) Scott Reef showing reef morphology (SI Sandy Islet) Note the increasing lagoon infill (a) from the north (Mermaid Reef; open lagoon) to Clerke Reef (centre) to the infilled and partitioned lagoon of Imperieuse Reef to the south. 
A comparison of the seismic results for Mermaid and Imperieuse Reefs provides additional information (Fig. 3). Firstly, the pattern of reef growth in both cases is similar to that of Scott Reef, with the Holocene reef growing in the accommodation provided by a saucer-shaped, subsided, last interglacial reef. The calculated subsidence rate since the last interglacial (Fig. 4) is $1 \mathrm{~m} / 6000 \mathrm{y}$, comparable to that of Scott Reef. However, there is a striking difference in the depth of the last interglacial reflector in the lagoon, which is uniformly $36 \mathrm{~m}$ below sea level in Mermaid Reef, but only $18 \mathrm{~m}$ below sea level in Imperieuse Reef (Fig. 4). Aside from indicating differential tectonic movement since the last interglacial (assuming the lagoon floor elevations were initially similar) these data indicate that the accommodation available for Holocene lagoon infill at Imperieuse Reef was only $50 \%$ of that available at Mermaid Reef, and this is an important control on the different amounts of lagoon infill observed between the two reefs.

At Scott Reef seismic data are available for South Reef only (COLLINS, 2002). The most striking feature of the seismic structure of South Scott Reef is the relationship between Holocene and last interglacial reef development. The saucer-shaped morphology of the last interglacial reef provided a template for Holocene reef growth, which duplicates the preceding reef and its morphology and has grown in the accommodation provided by subsidence of the last interglacial reef. This subsidence, up to $30 \mathrm{~m}$ at Scott Reef, is in contrast to the tectonic stability of the last interglacial in the Carnarvon and Perth Basins (Ningaloo and Houtman Abrolhos Reefs) where the last interglacial reef remains emergent by $2-5 \mathrm{~m}$ above sea level along $1000 \mathrm{~km}$ of coast (COLLINS et al., 2006) in these proximal shelf settings. Though local Quaternary subsidence data are lacking, the position of Scott Reef at the distal margin of the North West Shelf would ensure that subsidence due to hydro-isostatic loading of the shelf during transgression would be at a maximum there, and the calculated subsidence rate since the last interglacial is $0.04 \mathrm{~m} / 1000 \mathrm{y}$. This subsidence, along with global eustasy, has been a key control on the morphology of Scott Reef in the Late Quaternary.

\section{Holocene Evolution}

Though there are no seismic data for North Reef, the Holocene reef is thought to have developed on pre-existing Pleistocene reef rock as indicated by seismic lines shot on the neighboring South Reef. The data suggest a basal Holocene unconformity which most likely can be correlated with the R1 surface mapped for South Reef (see COLLINS, 2002) and provides an opportunity to document fore-reef development (see Fig. 5a; Table 1).
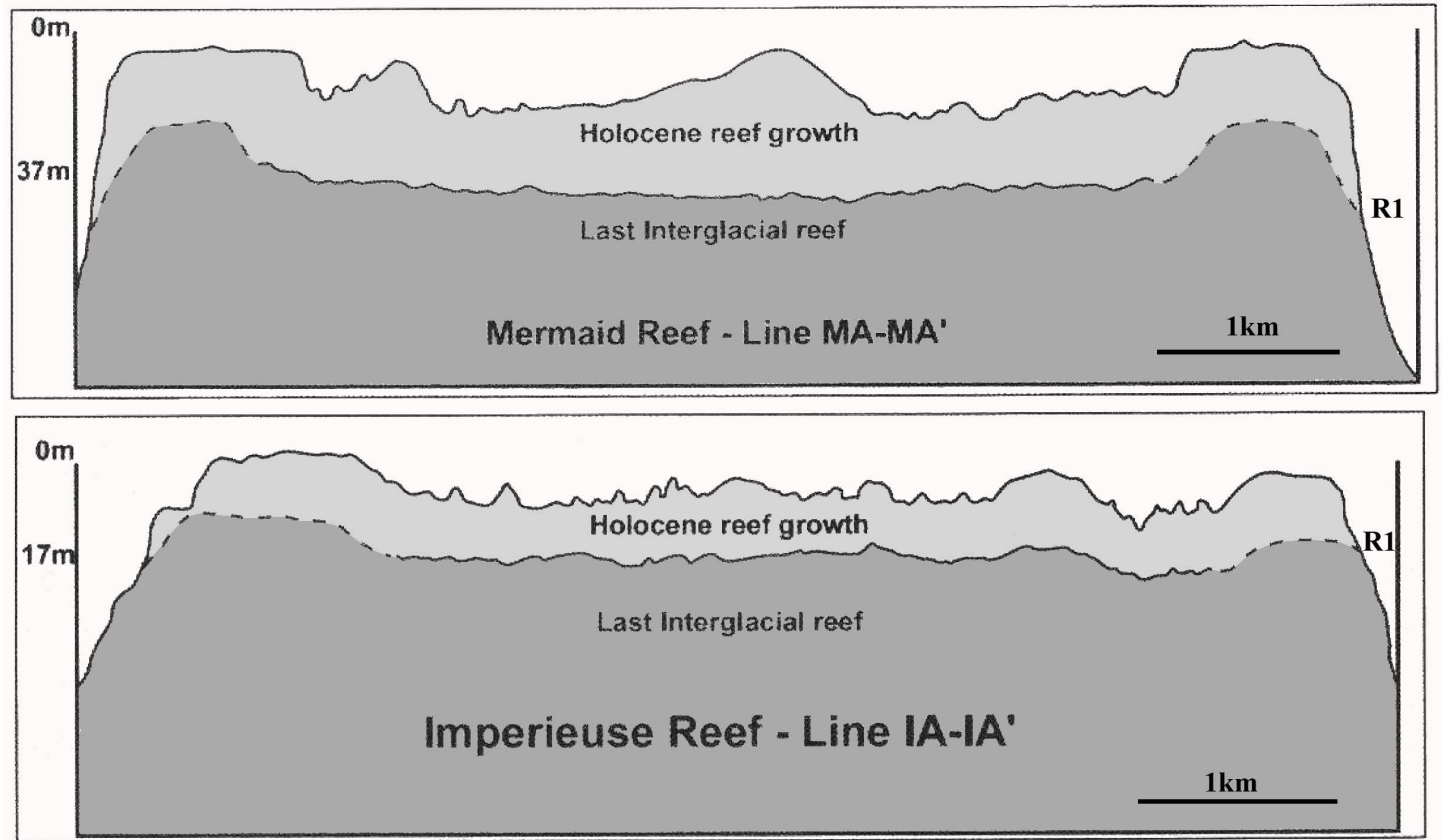

Fig. 3. West-east cross-sections of Mermaid and Imperieuse Reefs showing contrasting depth to pre-Holocene surface (R1) and differing amounts of Holocene buildup. (Redrawn from seismic sections; after Collins, 2002). For section locations see Fig. 2. 


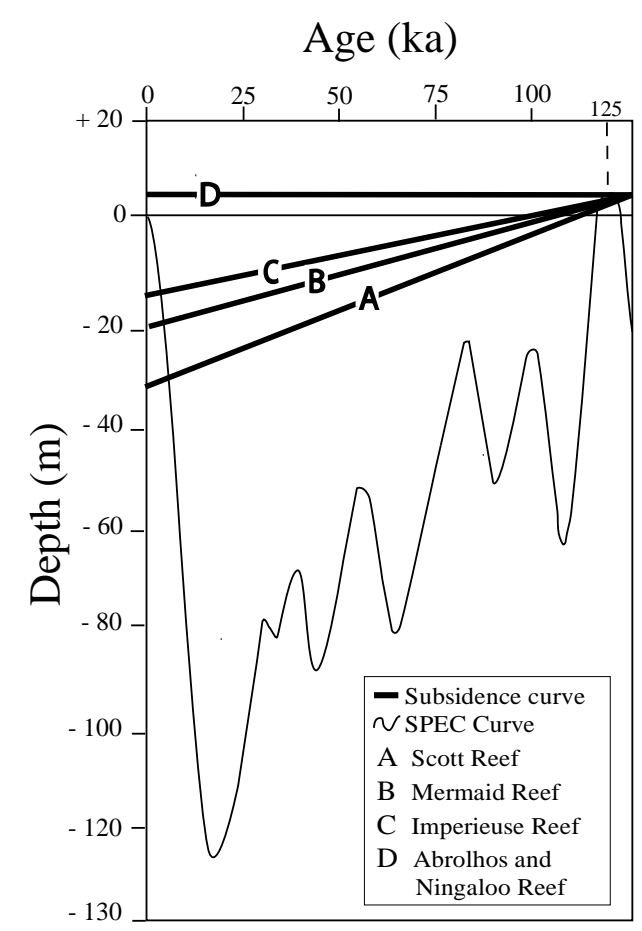

Fig. 4. Subsidence curve for available reef data along the continental shelf of western Australia: Scott Reef and Rowley Shoals indicating significant pre-Holocene subsidence for Kimberley shelf edge reefs, in contrast to the tectonically stable reefs (Ningaloo; Houtman Abrolhos) of southwest Australia, based on elevation changes of pre-Holocene (Last Interglacial) foundations.

The Holocene section is composed of porous but relatively unaltered reef framework with lesser amounts of carbonate sediment; some intervals, particularly those of branching corals, are rubbly, partly as a result of disruption by rotary drilling, and partly as a result of accumulation of both framework and infill material (Fig. 5a).

In a wide-ranging review of coral reef cores for Indo-Pacific reefs Montaggioni (2005) described the main coral communities and grouped them in three categories: shallow high-hydrodynamic energy environments (calcareous red algae and robustbranching corals), moderate energy environments (domal, tabular-branching and arborescent corals), and sheltered environments (association of arborescent, foliaceous and encrusting corals). In the fossil record, arborescent facies would represent communities from 0-20 metres in lower to middle parts of the forereef, whilst the domal association represents a semiexposed to sheltered, relatively deep environment of depth 10-15 m.

Using similar criteria the dominant frame builders in borehole NR1 are communities of two types: arborescent (branching) acroporids, and domal (massive) corals mainly poritids these exist as end member communities as well as in mixed associations. Reef initiation and early stages are characterized by coralline red algal crusts and domal coral, with gradual increasing contribution of branching corals. The mid to late Holocene is dominated by domal corals, and this facies is replaced by arborescent and domal facies during the Late Holocene to present.

The U-series data obtained for NR1 is in agreement with stratigraphic data and the expected position of the pre-Holocene unconformity (R1), corresponding to Marine Isotope Stage 1 (MIS1), at about $26.5 \mathrm{~m}$ core depth $(-38.41 \mathrm{~m}$ relative to Lowest Astronomical Tide; LAT) (Fig. 5b). The earliest dated settlement of reef building coral community recorded for the borehole is $9.7 \mathrm{ka}$ at $25.75 \mathrm{~m}$ core depth ($37.16 \mathrm{~m}$ LAT depth), followed by subsequent development during the Holocene.

Accretion rates are expected to vary during reef development, particularly in response to three factors: 1) regional occurrence of frame-building taxa; 2) primary frame building taxa related to the environment where the core is located; and 3) amount of reworked material locally generated (see Blanchon and Blakeway, 2003, for discussion). These generalizations suggest, perhaps not without controversy, that the nature of framework facies controls the accretion rates in reef environments (MONTAGGIONI, 2005), and the rates and modes of reef growth are expected to vary greatly within the same reef system, according to the zone considered (DAVIES et al., 1985).

The average accretion rate for the Holocene section of borehole NR1 is calculated as $2.64 \mathrm{~m} / \mathrm{ka}$. However, the accretion rate curve suggests four distinct phases of reef development (Fig. 5b; Table 1): an initial and faster development from reef initiation to $9.47 \mathrm{ka}$, characterized by an accretion rate of 11.47 $\mathrm{m} / \mathrm{ka}$; accretion rate gradually reduces to a minimum of $1.77 \mathrm{~m} / \mathrm{ka}$ during middle Holocene (6.4 $-2.7 \mathrm{ka}$ ), returning to increase to $3.09 \mathrm{~m} / \mathrm{ka}$ from late Holocene to present (Fig. 5b).

The variations in the accretion rates during the Holocene in borehole NR1 can be explained by the dominant coral communities during the middle Holocene (Fig. 5a, b), which is characterized by slow growing domal corals, such as the genus Porites. In contrast, higher accretion rates were recorded when there are greater proportions of arborescent forms (see also Blanchon and Blakeway 2003; Montaggioni 2005). Whilst the faster accretion rates recorded during reef initiation were expected, the more consistent slow rates for most of the Holocene (see Fig. 5b) are more representative of the overall Holocene reef development such as commonly found in Indo-Pacific reef margins(MONTAGGIONI, 
2005),resulting in the generation of a $25 \mathrm{~m}$ thick Holocene section at Scott Reef.

Vertical accretion potential can be converted to net calcification (see SMITH, f1983), a measure of carbonate production expressed in $\mathrm{kg} \mathrm{CaCO} 3 \mathrm{~m}^{-2}$ year $^{-1}$, taking into account a value for the porosity of the original framework and detritus fabric (about 50\%) and the density of an aragonite and calcite mixture (about $2.89 \mathrm{~g} / \mathrm{cm}^{3}$ ). Thus, slow-growing reefs are expected to range from $1-3 \mathrm{~kg} \mathrm{~m}^{-2}$ year $^{-1}$. These estimates are particularly important considering the dramatic worldwide prospect of ocean acidification (HOEGH-GULDBERG, 1999; HOEGH-GULDBERG et al., 2007). a)

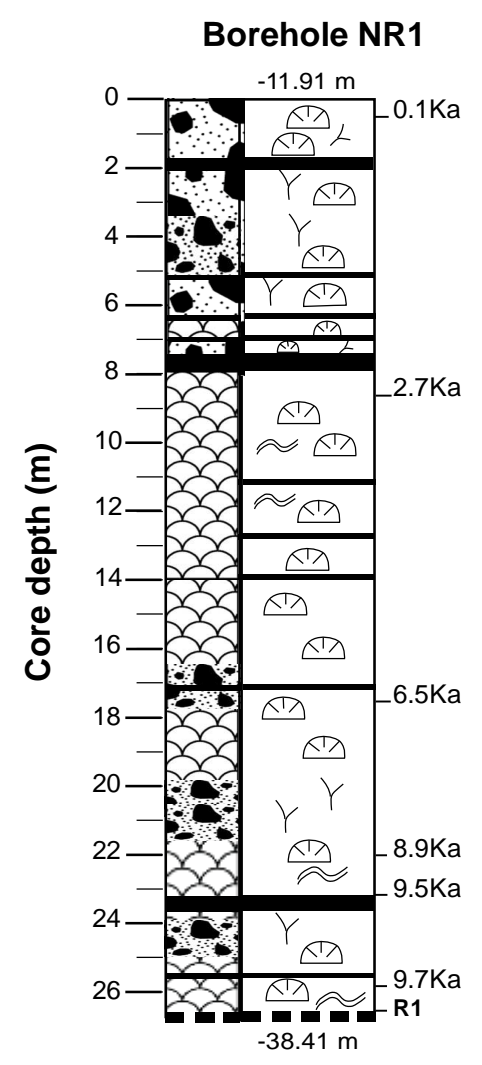

b)

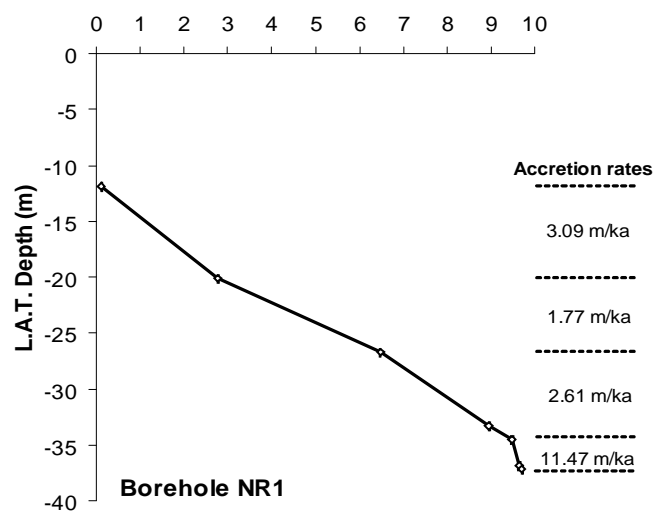

Fig. 5. Borehole NR1, Scott Reef. a) Holocene lithology, reef community and chronology; b) Growth history curve for reef front core site NR1, North Reef. For location of core see Fig. 2. 
Table 1. Summary of U-series dates for Holocene corals in borehole NR1, Scott Reef (North Reef). (LAT $=$ Lowest Astronomical Tide)

\begin{tabular}{|c|c|c|c|c|c|c|c|}
\hline $\begin{array}{l}\text { Sam } \\
\text { Name }\end{array}$ & NR 1 & NR 2 & NR 3 & NR 4 & NR 5 & NR 6 & NR 7 \\
\hline Core depth (m) & 0.50 & 8.70 & 15.25 & 21.85 & 23.10 & 25.45 & 25.75 \\
\hline Lat. Dept h (m) & -11.91 & -20.11 & -26.66 & -33.26 & -34.51 & -36.86 & -37.16 \\
\hline $\mathrm{U}(\mathrm{ppm})$ & 2.78214 & 3.01105 & 2.26852 & 2.54552 & 2.96861 & 3.49130 & 2.53676 \\
\hline $\pm 2 \mathrm{~s}$ & 0.00259 & 0.00204 & 0.00212 & 0.00249 & 0.00289 & 0.00307 & 0.00224 \\
\hline${ }^{232} \mathrm{Th}$ (ppb) & 0.21246 & 0.18583 & 0.07216 & 0.08351 & 0.19486 & 0.48429 & 0.41557 \\
\hline$\left({ }^{230} \mathrm{Th} /{ }^{232} \mathrm{Th}\right)$ & 52.96161 & 1425.68625 & 6316.65715 & 8410.06497 & 4423.68831 & 2132.95885 & 1816.23177 \\
\hline$\left(230^{\mathrm{Th}} / 238 \mathrm{U}\right)$ & 0.00133 & 0.02900 & 0.06622 & 0.09094 & 0.09570 & 0.09751 & 0.09806 \\
\hline $\pm 2 \mathrm{~s}$ & 0.00003 & 0.00007 & 0.00018 & 0.00018 & 0.00026 & 0.00020 & 0.00019 \\
\hline$\left({ }^{234} \mathrm{U} /{ }^{238} \mathrm{U}\right)$ & 1.15023 & 1.14885 & 1.14531 & 1.14806 & 1.14511 & 1.14637 & 1.14625 \\
\hline $\begin{array}{l} \pm 2 \mathrm{~s} \\
\text { uncorr. }{ }^{230} \mathrm{Th}\end{array}$ & 0.00110 & 0.00102 & 0.00139 & 0.00150 & 0.00130 & 0.00126 & 0.00114 \\
\hline Age (ka) & 0.12610 & 2.77881 & 6.46972 & 8.95912 & 9.47446 & 9.65038 & 9.70799 \\
\hline $\begin{array}{l} \pm 2 \mathrm{~s} \\
\text { corr. }{ }^{230} \mathrm{Th}\end{array}$ & 0.00250 & 0.00706 & 0.02030 & 0.02216 & 0.02903 & 0.02381 & 0.02184 \\
\hline Age (ka) & 0.12414 & 2.77722 & 6.46890 & 8.95828 & 9.47277 & 9.64681 & 9.70378 \\
\hline $\pm 2 \mathrm{~s}$ & 0.00268 & 0.00710 & 0.02030 & 0.02216 & 0.02904 & 0.02387 & 0.02193 \\
\hline $\begin{array}{l}\text { corr. Initial } \\
\left.{ }^{(234} \mathrm{U} /{ }^{238} \mathrm{U}\right)\end{array}$ & 1.15028 & 1.15003 & 1.14800 & 1.15187 & 1.14906 & 1.15043 & 1.15033 \\
\hline $\pm 2 s$ & 0.00110 & 0.00102 & 0.00142 & 0.00154 & 0.00133 & 0.00129 & 0.00117 \\
\hline $\begin{array}{l}\text { Accret. rate } \\
(\mathrm{m} / \mathrm{ka})\end{array}$ & & 3.09 & 1.77 & & 2.61 & & 11.47 \\
\hline
\end{tabular}

\section{Discussion}

Unlike the drowned Halimeda shoals of the Sahul Shelf further northward, all of the four Kimberley coral reefs described here have been able to survive as resilient reef systems and generate coral buildups up to $400 \mathrm{~m}$ high despite their position bordering a subsiding ramp margin. Proximity to the Java Trench and subduction zone to the north of Australia may have influenced relative subsidence. Whilst it is considered that subsidence of the northern margin of Australia has been rapid since the Miocene, there are few published subsidence rates. Neogene continental scale subsidence of the northern margin of Australia is estimated at $15-20 \mathrm{~m} / \mathrm{myr}$ by Sandiford (2007) and a similar rate was estimated for the Quaternary (MURRAY-WALLACE; BELPERIO, 1991) based on differential elevation of last interglacial terraces in southern and northern Australia.

At Scott Reef subsidence since the last interglacial has been more rapid $(0.04 \mathrm{~m} / \mathrm{kyr}$, about twice the long term rate). The seismic architecture of the Rowley Shoals reveals that differential preHolocene subsidence (and relative elevation of the pre-Holocene substrate; -18 m in Imperieuse Reef, -37 $\mathrm{m}$ in Mermaid Reef) has been an important determinant of Holocene morphology, particularly in the evolutionary series represented by the Rowley Shoals where the degree of lagoon infill is greatest where accommodation has been least (Imperieuse
Reef) and is least where accommodation has been greatest (Mermaid Reef; see Fig. 3). However the situation at Scott Reef is less clear (contrast the ring shaped North Reef and the crescent shaped South Reef and their relatively unfilled lagoons; Fig. 2 ), but the existence of a 400 metre deep "channel" between the two platforms is suggestive of an underlying structural control.

The core described for North Reef is significant because it serves to confirm previous seismic interpretations, but has additional importance. Ocean-facing reef cores are uncommon from high energy settings due to the difficulty of the logistics involved in their collection, and the core data presented here is therefore an important contribution to the characterization of the fore-reef zone of shelf edge reefs.

The Indo-Pacific reef growth phase (termed RG111) was characterised by moderate rates of sea level rise of $10 \mathrm{~mm} /$ year from 11 to about 7-6.5 ka BP until sea level stabilization at or $2 \mathrm{~m}$ above its present position (PIRAZZOLI, 1996). Pre-Holocene accommodation was created at a calculated subsidence rate of $0.25 \mathrm{~m} / \mathrm{ka}$ (COLLINS, 2002). However, short periods of rapid sea-level rise, such as the $6 \mathrm{~m}$ "jump" at $7.5 \mathrm{ka}$ reported by Blanchon et al. (2002), with accompanying pauses in reef growth, have been described. The dated Holocene core at Scott Reef provides an opportunity to evaluate the rate of sea level change and reef growth for Scott Reef compared with other reefs in the Indo-Pacific province. Reef 
initiation dated as 9.7 ka most likely lags behind sealevel, probably as a function of the position of the core in the reef system, and the lag depth between sea-level and the particular reef community dated (for example Acropora palmata, which grows close to sea-level, is absent from Indo-Pacific reefs).

The platform morphology that underlies the Holocene at Scott Reef is most likely heterogeneous within and across North and South reefs, as seen in South Reef seismic lines (COLLINS, 2002). The irregularities generated during the erosional period that produced the R1 hiatus are reflected in post glacial reef development as lower areas were inundated at the beginning of the event, whilst higher areas will record younger ages. The core onset age postdates the initial age assigned to Meltwater pulse 1B which is $11.5 \mathrm{ka}$ (BLANCHON; SHAW 1995), thereby bracketing the Holocene growth phase to this particular meltwater pulse and the subsequent sea-level rise.

Despite the medium to high hydrodynamic energy imposed by the $4 \mathrm{~m}$ tidal range, swell waves and occasional cyclones the communities that dominate in the Holocene section cored represent relatively low-wave energy settings due to their southeast facing. This may be influenced by protection afforded by the proximity of the South Reef platform. The arcuate reef orientation combined with wave refraction provides a spectrum of reef front wave energies, from high to moderate to low, and more westerly reef front locations are likely to experience higher fair-weather wave energy than the study site. However, with a $4 \mathrm{~m}$ tidal range tidal energy is always high, and the consistent (1 per 3 years) passage of tropical cyclones through the region ensures a significant storm influence on reef growth.

Coral reefs worldwide are under increasing threat from anthropogenically induced climate change including temperature-induced coral bleaching (HOEGH-GULDBERG, 1999; WILKINSON, 2008) which is often exacerbated by human activities. The remoteness of the Kimberley region provides little protection from the former but is likely to continue to limit the latter impacts. Further biological and geological research is needed in this region to examine reef response to past climate and sea level change and to provide analogue information for future climate change management. This study demonstrates the resilience of reefs on a rapidly subsiding continental margin whilst also linking Holocene reef morphology to the relative amount of pre - Holocene subsidence.

\section{ACKNOWLEDGEMENTS}

Marine seismic surveys were conducted during Voyage FR05/00 of the CSIRO vessel RV Franklin, and the shipboard scientists and crew are thanked for support and assistance. Geoscience
Australia assisted with access to seismic equipment. The project was also supported by Woodside Energy Ltd who provided access to the Scott Reef core. We thank Jian-xin Zhao and Dingchuan Qu of the University of Queensland for U-series age determinations; Core Laboratories Perth, for help with core databases; Mr. Paul Davill of the National Tidal Centre, Bureau of Meteorology (South Australia), for access to tidal data; and Ms. Alex Stevens (Curtin University) for drafting of some figures. Thanks also to colleagues in IGCP526, and to reviewers for helpful suggestions.

\section{REFERENCES}

BERRY, P. F.; MARSH, L. M. Faunal survey of the Roley Shoals, Scott Reef and Seringapatam Reef, northwestern Australia. Records of the Western Australian Museum. Supplement, 25 p., 1986.

BOC OF AUSTRALIA, LTD. Scott Reef 1 Well Completion Report. 1971a. (unpublished).

BOC OF AUSTRALIA, LTD. North Scott Reef 1 Well Completion Report, 1971b. (unpublished).

BLANCHON, P.; BLAKEWAY, D. Are catch-up reefs an artefact of coring? Sedimentology. v. 50, p. 1271-1282. 2003.

BLANCHON, P.; JONES, B.; FORD, D. C. Discovery of a submerged relic reef and shoreline off Grand Cayman: further support for an early Holocene jump in sea level. Sedim. Geol., v. 147, p. 253-270. 2002.

BLANCHON, P.; SHAW, J. Reef drowning during the last deglaciation: Evidence for catastrophic sea-level rise and ice-sheet collapse. Geology. v. 23; v. 1, p. 4-8.1995.

CHIN, A.; SWEATMAN, H.; FORBES, S.; PERKS, H.; WALKER, R.; JONES, G.; WILLIAMSON, D.; EVANS, R.; HARTLEY, F.; ARMSTRONG, S.; MALCOLM, H.; EDGAR G. Status of the coral Reefs in Australia and Papua New Guinea. In: WILKINSON, C. (Ed.). Status of Coral Reefs of the World. Global Coral Reef Monitoring Network, Reef and Rainforest Research Centre, 2008. p. 159-176.

COLLINS, L. B. Tertiary Foundations and Quaternary Evolution of Coral Reef Systems of Australia's North West Shelf. In: KEEP, M; MOSS, S.J., (Ed). The Sedimentary Basis of Western Australia 3. In: PETROLEUM EXPLORATION SOCIETY OF AUSTRALIA SYMPOSIUM, Perth, WA, 2002. Proc. .... p. 129-152.

COLLINS, L. B.; ZHAO, J-X.; FREEMAN, H. A high precision record of mid-late Holocene sea-level events from emergent coral pavements in the Houtman Abrolhos Islands, southwest Australia. Quater. Intern. v. $145 / 146$, p. $78-85.2006$.

DAVIES, P. J.; MARSHALL, J. F.; HOPLEY, D. Relationships between reef growth and sea level in the Great Barrier Reef. INTERNATIONAl REEF CONGRESS, 5., Tahiti, 1985. Proc. ...v. 3, p. 95-103, 1985.

DONE, T. J.; WILLIAMS, D. McB.; SPEARE, P.; TURAK, E.; DEVANTIER, L.M.; NEWMAN, S.J.; HUTCHINS, J. B. Surveys of coral and reef communities at Scott Reef and Rowley Shoals. Townsville, Australia: Australian Institute of Marine Science, 1994. 46 p. 
EMBRY, A. F.; KLOVAN, J. E. A late Devonian reef tract on Northeastern Banks Island. Bull. Canad. Petrol. Geol., Calgary, v. 19, p. 730-781. 1971.

FAIRBRIDGE, R. W. Recent and Pleistocene coral reefs of Australia, J. Geol., v. 58 p. 330-401. 1950

FANG, F; MORROW, R. Evolution, movement and decay of warm core Leeuwin Current eddies. Deep-sea Res. II, v. 50, p. 2245-2261, 2003.

GILMOUR, J. P.; SMITH, L. D. Category 5 cyclone at Scott Reef, northwestern Australia. Coral Reefs, v. 25, p. 200. 2006.

HARRIS, P. T.; BAKER, E. K.; COLE, A. R. Physical sedimentology of the Australian continental shelf, with emphasis on Late Quaternary deposits in major shipping channels, port approaches and choke points. Ocean Sciences Institute, Report 51, University of Sydney, $1991.505 \mathrm{p}$

HAYES, M. O. Morphology of sand accumulation in estuaries: an introduction to the symposium. In: CRONIN, L.E. (Ed.). Estuarine Research.. New York: Academic Press, 1975. v. II, p. 3-22.

HEYWARD, A.; PINCERATTO, E.; SMITH, L. Big Bank shoals of the Timor Sea, an environment resource atlas. BHP Petroleum, 1997. $115 \mathrm{p}$.

HOEGH-GULDBERG, O. Climate change, coral bleaching and the future of the world's coral reefs. Mar. Freshw. Res., v. 50, p. 839-866. 1999.

HOEGH-GULDBERG, O.; MUMBY, P. J.; HOOTEN, A. J.; STENECK, R. S.; GREENFIELD, P.; GOMEZ, E.; HARVELL, C. D.; SALE, P. F.; EDWARDS, A. J.; CALDEIRA, K.; KNOWLTON, N.; EAKIN, C.M.; IGLESIAS-PRIETO, R.; MUTHIGA, N.; BRADBURY, R. H.; DUBI, A.; HATZIOLOS, M. E. Coral reefs under rapid climate change and ocean acidification. Science. v. 318, p. 1737-1742, 2007.

HOPLEY, D.; SMITHERS, S.; PARNELL, K. Geomorphology of the Great Barrier Reef: Development, diversity, change: Cambridge: Cambridge Univ. Press, 2007. 532 p.

LOUGH, J. M. Coastal climate of northwest Australia and comparisons with the Great Barrier Reef: 1960 to 1992. Coral Reefs. v. 17, p.351-367, 1998.

LAVERING, I. H. Quaternary and modern environments of the Van Diemen Rise. Timor Sea, and potential effects of additional petroleum exploration activity. J. Austral. Geol. Geophys., v. 13, p. 281-292, 1993.

MONTAGGIONI, L. F. History of Indo-Pacific coral reef systems since the last glaciation: Development patterns ans controlling factors. Earth-Sci. Rev., v. 71, p. 1-75, 2005.

MURRAY-WALLACE, C. V.; BELPERIO, A. P.The last interglacial shoreline in Australia - a review. Quat. Sci Revs, v. 10 , p. 441-461, 1991.

NATIONAL TIDAL CENTER http://www.bom.gov.au/oceanography/tides/MAPS/broo me range.shtml. 2009a.

NATIONAL TIDAL CENTER http://www.bom.gov.au/oceanography/tides/MAPS/yamd er range.shtml. 2009b.

PEARCE, A. F.; GRIFFITHS, R. W. The mesoscale structure of the Leeuwin Current. J. Geophys. Res., v. C96, p. 16739-16757, 1991.

PIRAZZOLI, P. A. Sea-level changes: the last 20.000 years New York: John Wiley, 1996. 211 p.
READ, J. F. Carbonate platform facies models. Am. Assoc. Pet. Geol. Bull. v. 69, p. 1- 21, 1985.

SANDIFORD, M. The tilting continent: A new constraint on the dynamic topographic field from Australia. Earth planet. Sci. Letts , v. 261, p. 152-163, 2007.

SMITH, S. V. Coral reef calcification. In: BARNES, D.J. (Ed.), Perspectives on Coral Reefs. Manuka, Australia: Brian Clouston Publ., 1983. p. 240- 247.

SMITH, L. D.; GILMOUR, J. P.; HEYWARD, A. J.; REES, M. Mass-bleaching, mortality and slow recovery of three common groups of scleractinian at an isolated reef. In: INTERNATIONAL CORAL REEF SYMPOSIUM, 10., Japan, 2006. Proc.... p. 651-656, 2006.

SMITH, L. D.; GILMOUR, J. P.; HEYWARD, A. J. Resilience of coral communities on an isolated system of reefs following catastrophic mass-bleaching. Coral Reefs, v. 27, p. 197-205. 2008.

STEPHENSON, A. E.; CADMAN, S. Browse Basin, northwest Australia: the evolution, palaeogeography and petroleum potential of a passive continental margin, Palaeo. Palaeo. Palaeo. v. 111, p. 337-366. 1994.

STRUCKMEYER, H. I. M.; BELVIN, J. E.; SAYERS, J.; TOTTERDELL, J. M.; BAXTER, K.; CATHRO, D. L. Structural evolution of the Browse Basin, North West Shelf. In: PURCELL, P. G.; PURCELL, R. R., (Ed.). The Sedimentary Basins of Western Australia, 2:. PETROLEUM EXPLORATION SOCIETY OF AUSTRALIA SYMPOSIUM, Perth, 1998. Proc... p. 345-366, 1998

SYMONDS, P. A.; COLLINS, C. D. N.; BRADSHAW, J. Deep structure of the Browse Basin: implications for basin development and petroleum exploration. In: PURCELL, P. G.; PURCELL, R. R.. (Ed.)., The Sedimentary Basins of Western Australia. PETROLEUM EXPLORATION SOCIETY OF AUSTRALIA SYMPOSIUM, Perth, 1994. Proc. ... p. 315-331, 1994.

VERON, J. E. N. A biogeographic database of Hermatypic Corals. Species of the Central Indo-Pacific. Genera of the World. Australian Institute of Marine Science Monograph Series, Townsville, v. 10, 433 p., 1993.

WILKINSON, C. (Ed.). Status of Coral Reefs of the World. Global Coral Reef Monitoring Network, Reef and Rainforest Research Centre., 2008. p. 5-19.

YU, K.-F.; ZHAO, J.-X.; SHI, Q.; CHEN, T.-G.; WANG, P.X.; COLLERSON, K. D.; LIU, T.-S. U-series dating of dead Porites corals in the South China Sea: evidence for episodic coral mortality over the past two centuries. Quat. Geochron. v. 1, p. 129-141. 2006.

ZHAO, J. X.; HU, K.; COLLERSON, K. D.; XU, H. K. Thermal ionization mass spectrometry U-series dating of a hominid site near Nanjing, China. Geology. v. 29, n. 1, p. 27-30, 2001.

ZHU, Z. Z.; COLLINS, L. B.; WYRWOLL, K-H.; CHEN, J.; WASSERBURG, G.; EISENHAUER, A. High precision U-series dating of Last Interglacial events by mass spectrometry; Houtman Abrolhos Islands. Earth plan. Sci. Letts, v. 118; p. 281-293. 1993.

(Manuscript received 28 August 2009; revised 14 December 2009; accepted 03 March 2010) 